\title{
Electing the councils - get involved!
}

Could you help represent the interests and views of colleagues, and contribute to national policy, by standing for election to one of the BDA's country councils?

The BDA's democratic process now moves on to the election of councils in each country of the United Kingdom, following the election of the 15 strong Principal Executive Committee (PEC). This is another crucial step in implementing the Association's new governance structure.

\section{HOW THE COUNTRY COUNCILS FIT INTO THE NEW STRUCTURE}

The new PEC has overall responsibility for the control and direction of the policy and affairs of the Association. In its role the PEC will draw on a range of policy determining forums to inform its direction and decision making. These will include the craft and cohort based committees that focus on the interests of constituent parts of the profession, such as the General Dental Practice Committee, Salaried Dentists Committee, and Students Committee. There will be issue specific forums too such as the Health and Science Committee, and a new committee for Ethics, Education and the Dental Team. The new Articles of Association empower the PEC to open and close other standing committees to help it in its work.

Central to the structure of policy determining forums, will be councils established for each country of the United Kingdom. A new English Council will join the established councils for Scotland, Wales and Northern Ireland. Their job will be to consider and advise the PEC on all matters relating to dentistry in the country concerned, and to liaise with branches and sections.
Representatives from the country councils will come together in a United Kingdom Council that will focus on UK wide issues. The UK Council will have a significant role through the appointment of a scrutiny committee that will undertake an annual performance review with senior staff and PEC members. The new Articles of Association empower the United Kingdom Council to convene an EGM to consider a motion to dissolve the PEC and call for fresh elections if necessary.

The councils will be elected from the branches (though they will also include representatives from the craft committees), and nominations are now invited from BDA members who are interested in standing in their local branch.

\section{RESPONSIBILITIES OF COUNCIL MEMBERS}

So what is involved in being a member of a country council?

Typically the responsibilities will include:

- Attending all meetings of the country council - around three a year, but each council will decide how many it needs to conduct its business

- Attending all meetings of the UK Council - usually two a year (these won't necessarily involve all elected members of the councils in Scotland, Wales and Northern Ireland)

- Possibly sitting on 1-2 sub committees or issue specific forums

- Liaising with local branch officers and members, attending local meetings as appropriate

- Attending general meetings of the Association.

It is anticipated that the approximate time commitment for an ordinary country council member will be around 6-8 days per year depending on whether the member also participates on a sub committee or issue specific forum. Some meetings may be held on a Saturday. There will also be electronic communication between meetings.

\section{ROLE OF THE CHAIR OF A COUNTRY COUNCIL}

The most significant key office holder elected by members of a country council will be the chair, who must be elected from those directly elected from the branches. The chair will have the following main areas of responsibility:

- Chairing and leading the agenda preparation for regular meetings of the council

- Ensuring that the views, concerns and priorities of members in the country concerned are communicated to the Principal Executive Committee (PEC)

- Ensuring that the council receives regular reports from the PEC on its activities

- Liaising with the Chair of the PEC, and senior BDA staff, to ensure appropriate consideration and input by the council to policy issues 
- Liaising with the chairs of the other country councils to ensure mutual briefing on all relevant issues, and that issues are appropriately identified for discussion in the United Kingdom Council

- Chairing meetings of the UK Council, in rotation with the chairs of the other country councils

- Attending meetings of the UK Council's Scrutiny Committee

- Attending internal and external meetings as appropriate.

It is anticipated that the approximate time commitment will be around 15 days per year.

Each council may also elect a deputy chair, though apart from standing in for the chair as appropriate, it is not anticipated that the time commitment for this role will be significantly more than a normal member of the council.

\section{REMUNERATION}

The remuneration for work on each country council will, in the case of GDPs, be subject to the four session rule. This means that the first four sessions (a session is a half day) are not paid. Sessions are not payable for meetings held at the weekend, though expenses will be paid. Full details of the remuneration and expenses policy, and sessional rates, are available on the website (link below).

\section{TERM OF OFFICE}

All candidates elected to the councils in 2012 shall serve until February 2015. Thereafter each council will be elected for a three year term.

\section{INDUCTION, SUPPORT}

AND TRAINING

There will be an induction programme for those elected, and appropriate training. Members will also have 'civil service' advice and support from the Chief Executive and his staff.

\section{TIMETABLE}

Nominations for election to each country council are now open, and completed nomination forms must be returned by $12 \mathrm{pm}$ on Wednesday 11 July 2012. Further information on the elections in each country, including a downloadable nomination form, is available on the BDA website at www.bda.org/councils. If you want a hard copy election pack sent to you, contact Stephen Skelton by e mailing your request to s.skelton@bda.org or telephoning 02075634141. 